\title{
WEB-BASED DECISION SUPPORT SYSTEM FOR GUEST STAR DETERMINATION IN E-MARKETPLACE USING WEIGHTED PRODUCT METHOD
}

\author{
Asih Pujiastuti*, Anggraini Kusumaningrum, Muhammad Ali Sofyan \\ Departemen Informatika \\ Sekolah Tinggi Teknologi Adisutjipto \\ Jalan Janti Blok R Lanud Adisutjipto, Yogyakarta \\ Email Korespondensi : *asihpuji@stta.ac.id
}

Received: November 8, 2020; Accepted : December 1, 2020; Published : December 1, 2020

\begin{abstract}
At an event, the event organizer usually requires guest stars as performers. Event organizers often find it difficult to find a guest star that suits their needs for their event. The purpose of this research is to build an e-marketplace application as a web-based decision support system that can be used to find alternative decisions to choose guest stars according to the criteria using product weighting methods. The weighted product method is one of the methods that can be applied to web-based decision support system applications for determining guest stars in e-marketplaces. There are three criteria used to determine guest stars in this e-marketplace, these criteria are the type of show, price and location. As for the alternatives that were tested, there were nine alternatives consisting of guest stars in Yogyakarta. Functionality testing is carried out using the black box method and the result is that all functions and validation buttons on the e-marketplace can function properly. The result of calculation using the weighted product method is the guest star with the highest yield is Frengki Sermadi (13,5\%), while the guest star with the lowest result is Sanggar Titik Dua $(8,8 \%)$.
\end{abstract}

Keyword: Decision Support System, Weighted Product, E-marketplace, Guest star, Website.

\section{Latar Belakang Masalah}

Berbagi informasi semakin terasa mudah di semua bidang, seperti bidang pendidikan, bidang kesehatan, bidang ekonomi dan lain sebagainya berkat peran serta teknologi. Aktivitas pemasaran, pembelian, dan penjualan barang, maupun jasa juga sangat mudah dengan memanfaatkan jaringan komputer. E-commerce adalah transaksi perdagangan melalui media elektronik yang terhubung dengan internet [1]. E-commerce mempunyai beberapa model, salah satunya adalah electronic marketplace (E-marketplace).

E-marketplace didefinisikan sebagai sebuah tempat jual beli online yang dikelola oleh satu pihak yaitu developer, kemudian produk yang ada di dalamnya disediakan oleh pihak lain yaitu penjual [2]. Di e-marketplace, penjual tidak hanya dapat menawarkan barang saja, namun jasa juga dapat ditawarkan. Jasa merupakan bisnis yang mulai berkembang di Indonesia, mulai dari jasa perbaikan, jasa pemeliharaan rumah, bahkan jasa penyelenggara pertunjukan (event).

Hampir setiap hari akan ada event yang digelar di beberapa tempat, baik itu berskala besar maupun kecil. Event dari mulai tari, musik, komedi, dan lain sebagainya seakan 
menjadi kebutuhan untuk melepas penat dan meninggalkan sejenak kesibukan. Dalam sebuah event biasanya akan ada bintang tamu (guest star) yang diminta penyelenggara acara untuk tampil dan mengisi sebuah event. Guest star adalah salah satu elemen penting dalam event. Guest star juga sangat mempengaruhi banyaknya penonton dan seberapa meriahnya sebuah event. Namun, para penyelenggara event sering kali kesulitan dalam mencari guest star yang sesuai dengan kebutuhan untuk acaranya. Di sisi lain, para pengisi event seperti musisi, penari dan lain sebagainya juga kesulitan dalam mempromosikan jasanya. Sistem pendukung keputusan merupakan sebuah aplikasi yang dapat digunakan sebagai alat bantu untuk pengambilan keputusan bagi pengguna [3][4][5]. Untuk mendapatkan guest star yang sesuai dengan kriteria yang diharapkan, dapat menggunakan beberapa metode sistem pendukung keputusan. Salah satu metode yang dapat digunakan adalah metode Weighted Product (WP). Metode WP dapat diimplementasikan pada sistem pendukung keputusan, sehingga dapat mempermudah pengguna dalam mengambil keputusan [6]. Metode WP menggunakan perkalian untuk menghubungkan rating atribut, dimana rating setiap atribut harus dipangkatkan dahulu dengan bobot atribut yang bersangkutan [7].

\section{Metodologi Penelitian}

Rujukan Data penelitian diperoleh dari kuisioner yang diajukan kepada responden. Responden tersebut berasal dari pihak-pihak yang sering mengadakan sebuah event yang berjumlah 36 responden. Kemudian data yang sudah didapatkan digunakan untuk menentukan urutan prioritas setiap kriteria, mana kriteria yang menjadi prioritas utama dan mana yang prioritas akhir. Kemudian kriteria diproses untuk melakukan perhitungan dalam menentukan guest star melalui metode WP.

Kriteria yang digunakan dalam penentuan guest star ini ada 3 kriteria, yaitu jenis pertunjukan, harga, dan kemudian jarak atau dalam sistem disebut lokasi. Hasil kuisioner, responden memilih jenis pertunjukan sebagai prioritas kriteria yang paling utama yaitu dengan jumlah pemilih 19 responden, dengan presentase sebesar 52.8\%. Sedangkan untuk prioritas kriteria nomer dua adalah harga dengan jumlah pemilih sebanyak 10 responden, dengan presentase sebesar 27.8\%. Dan yang terakhir adalah jarak dengan pemilih 7 responden, dengan presentase sebesar $19.4 \%$.

\subsection{Metode Weighted Product (WP)}

Metode weighted product menggunakan perkalian untuk menghubungkan rating atribut, dimana setiap rating atribut harus dipangkatkan dahulu dengan bobot atribut yang bersangkutan [7]. Langkah perhitungan WP sebagai berikut:

Penentuan nilai $\mathrm{W}$ :

$$
W_{i}=\frac{W_{j}}{\Sigma W_{j}}
$$

W adalah bobot dari setiap kriteria. Nilai W berada antara 0 sampai 1, dan akumulasi W adalah 1. Penentuan nilai bobot $\mathrm{S}$, sebagai berikut [9] :

$$
S_{i}=\prod_{j=1}^{n} X_{i j} W_{j}
$$

$S_{i} \quad=$ hasil normalisasi keputusan pada alternatif ke-i,

$X_{i j} \quad=$ merupakan rating alternatif per atribut, i merupakan alternatif, $\mathrm{j}$ merupakan atribut.

$W_{j} \quad=$ adalah pangkat bernilai positif untuk atribut keuntungan, dan bernilai negatif untuk atribut biaya. 
Preferensi relatif dari setiap alternatif, diberikan sebagai:

$$
V_{i}=\frac{S_{i}}{\Sigma_{i=1}^{m} S_{i}}
$$

dengan $\mathrm{i}=1,2 \ldots, \mathrm{m}$

\subsection{Prinsip Kerja Sistem}

Perinsip kerja sistem dalam penelitian akan dijelaskan menggunakan flowchart dan data flow diagram.

\subsubsection{Flowchart}

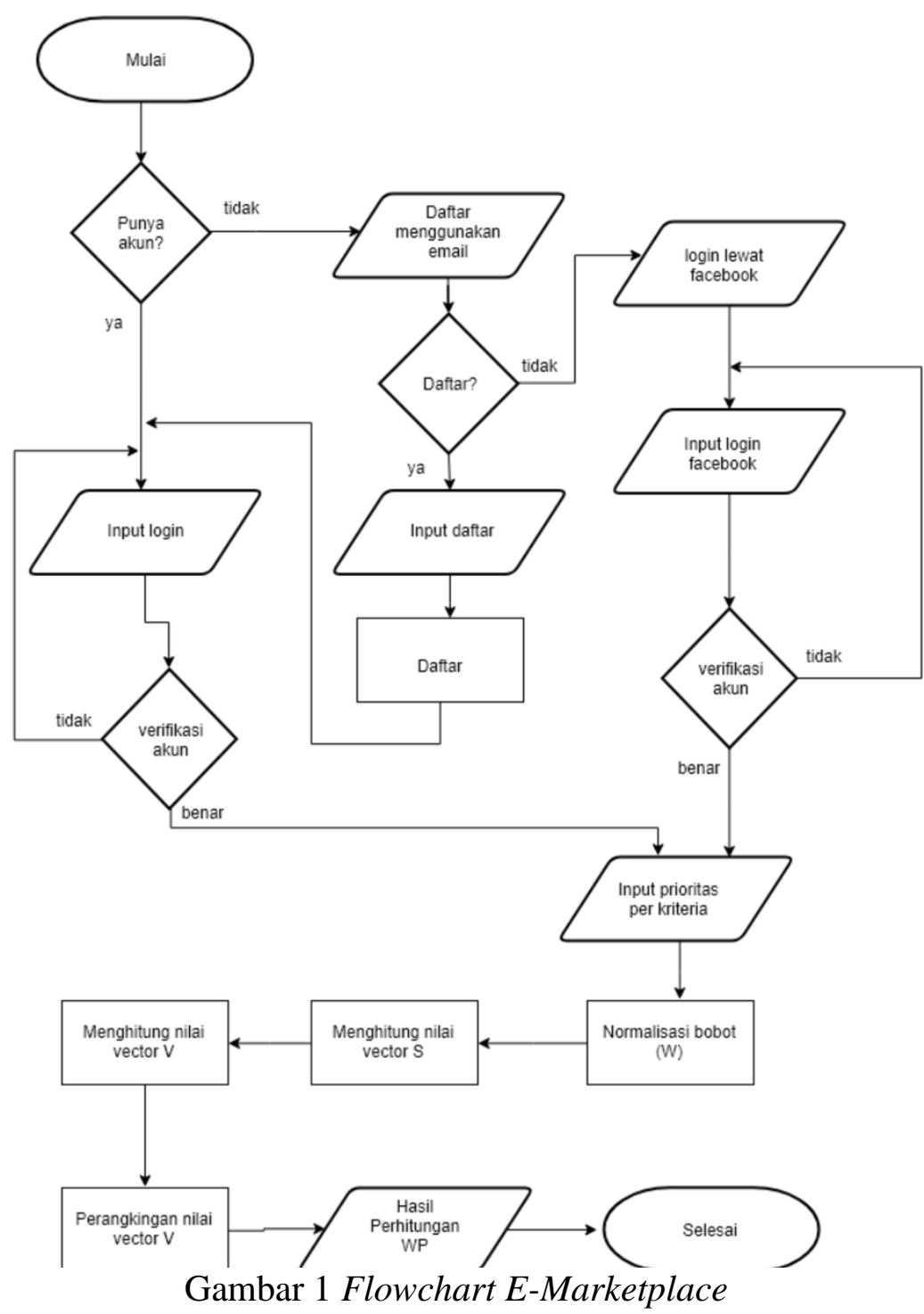

Pada flowchart e-marketplace ini penyelenggara bisa login menggunakan 2 cara, yaitu dengan facebook atau dengan email. Setelah berhasil login, penyelenggara dapat menginputkan prioritas per kriteria. Kemudian setelah menginputkan prioritas per kriteria akan didapatkan bobot per kriteria dan selanjutnya bobot di proses dengan metode weighted product. Setelah didapatkan hasil dari perhitungan, penyelenggara dapat mengajukan tawaran 
kepada guest star dan kemudian menunggu konfirmasi tawaran. Perancangan flowchart emarkteplace dapat dilihat pada Gambar 1.

Sedangkan pada flowchart dashboard, guest star dapat login atau jika belum mempunyai akun maka harus mendaftar terlebih dahulu. Setelah berhasil login maka akan diarahkan ke dashboard guest star. Pada dashboard guest star terdapat menu tawaran, yang berisi tawaran dari penyelenggara event yang harus di konfirmasi. Profil, yang berisi menu data guest star yang akan tampil di halaman e-marketplace. Kemudian akun, dimana guest star dapat mengubah password akun. Perancangan flowchart dashboard dapat dilihat pada Gambar 2.

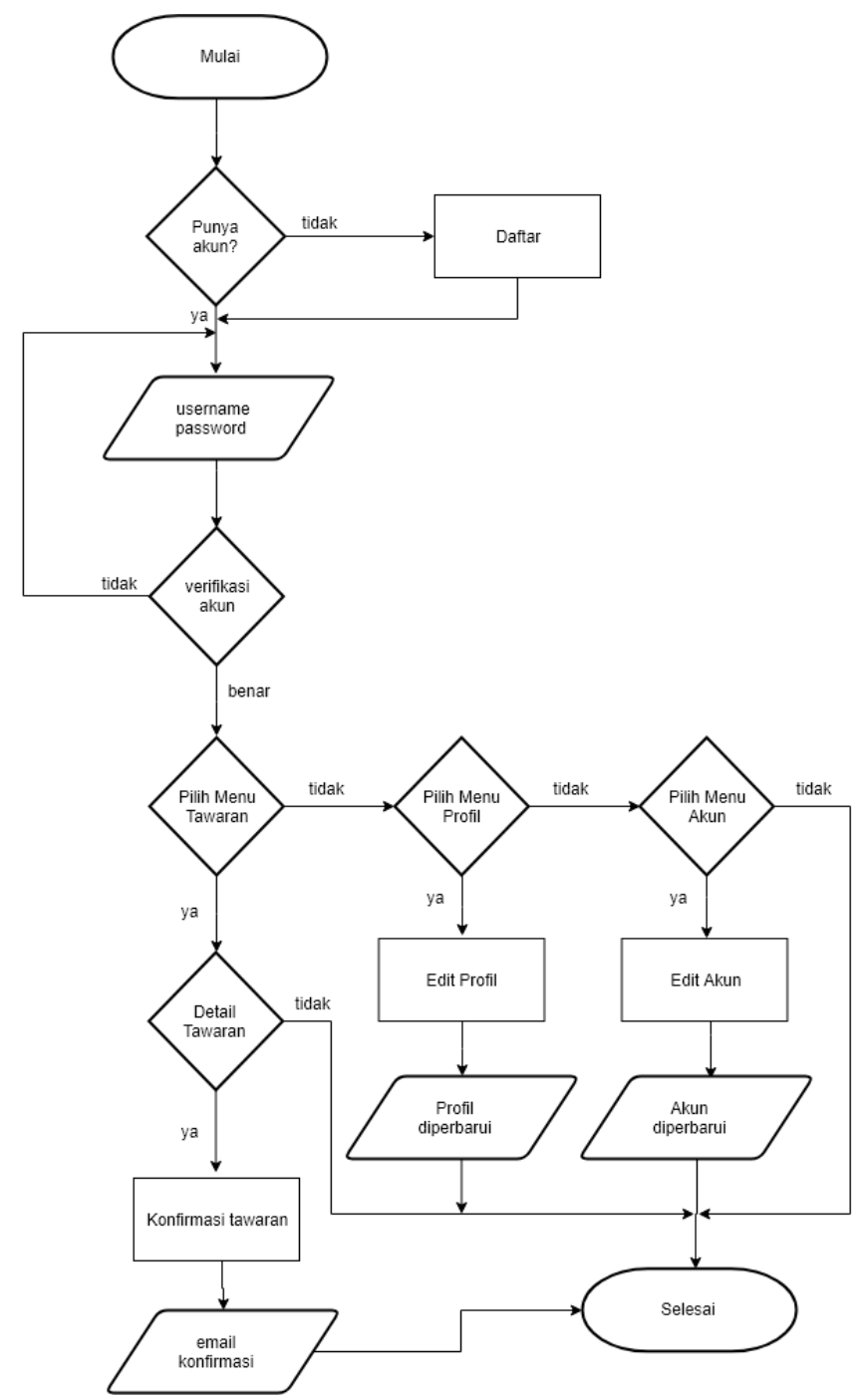

Gambar 2 Flowchart Dashboard

\subsubsection{Data Flow Diagram (DFD)}

Data flow diagram merupakan suatu diagram yang menggunakan notasi-notasi untuk menggambarkan arus dari data sistem [10]. Diagram konteks mewakili keseluruhan sistem. Pada diagram konteks e-marketplace ini penyelenggara event dapat melakukan login, input bobot dan mengajukan penawaran. Kemudian penyelenggara akan mendapatkan hasil rekomendasi guest star dan menerima konfirmasi tawaran. Sedangkan untuk pengisi event atau guest star dapat login, update data diri dan konfirmasi tawaran. Kemudian akan mendapat tawaran, seperti Gambar 3. 
Web-Based Decision Support System for Guest Star Determination in E-Marketplace .....

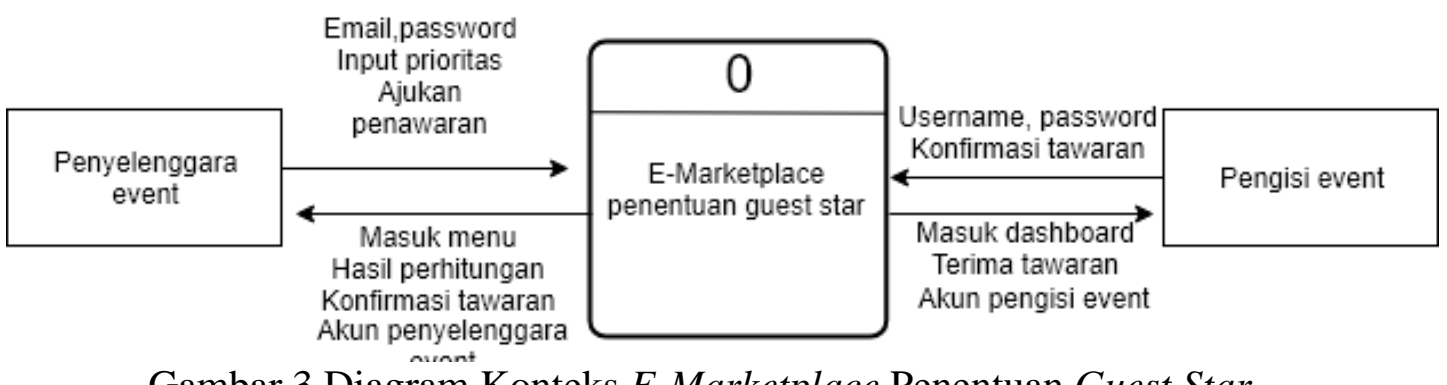

Gambar 3 Diagram Konteks E-Marketplace Penentuan Guest Star

\section{Hasil dan Pembahasan}

Hasil dan pembahasan dibagi menjadi dua, yaitu hasil implementasi dan pembahasan untuk perhitungan weighted product.

\subsection{Hasil Implementasi}

Hasil implementasi dibagi menjadi dua, yaitu implementasi e-marketplace yang digunakan penyelenggara event dalam mencari guest star. Dan implementasi dashboard yang digunakan guest star untuk memperbarui informasi dan juga konfirmasi tawaran

\subsubsection{Implementasi e-marketplace}

Pada e-marketplace, penyelenggara event selaku user dapat mencari guest star dengan memasukan beberapa kriteria kemudian akan ditampilkan hasil dari perhitungan weighted product untuk membantu dalam menentukan guest star yang ingin diundang. Setelah itu, user dapat mengajukan tawaran kepada guest star yang telah dipilih.

Pada Gambar 4 merupakan implementasi untuk menu utama, dimana akan ditampilkan dua kriteria yaitu jenis pertunjukan dan lokasi. Dari kriteria-kriteria tersebut user diminta menentukan prioritas dari yang pertama sampai yang terakhir untuk nanti menentukan bobot setiap kriteria. Sedangkan untuk kriteria harga akan langsung diambil dari database untuk nantinya ikut dihitung menggunakan metode weighted product.

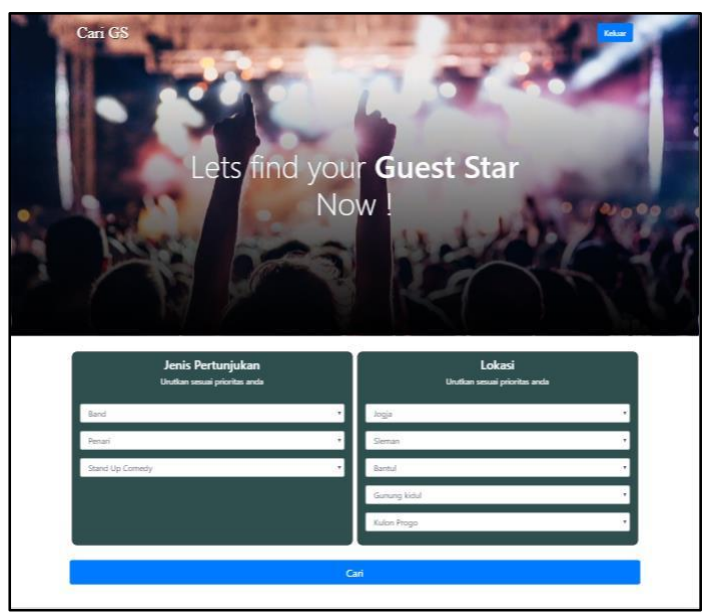

Gambar 4 Tampilan Menu Utama

Pada Gambar 5 merupakan implementasi untuk hasil perhitungan, dimana akan ditampilkan hasil dari perhitungan weighted product dan diurutkan dari alternatif yang memiliki nilai tertinggi. Di sebelah kiri ada sidebar yang berisi urutan prioritas per kriteria yang sudah dimasukkan sebelumnya. 


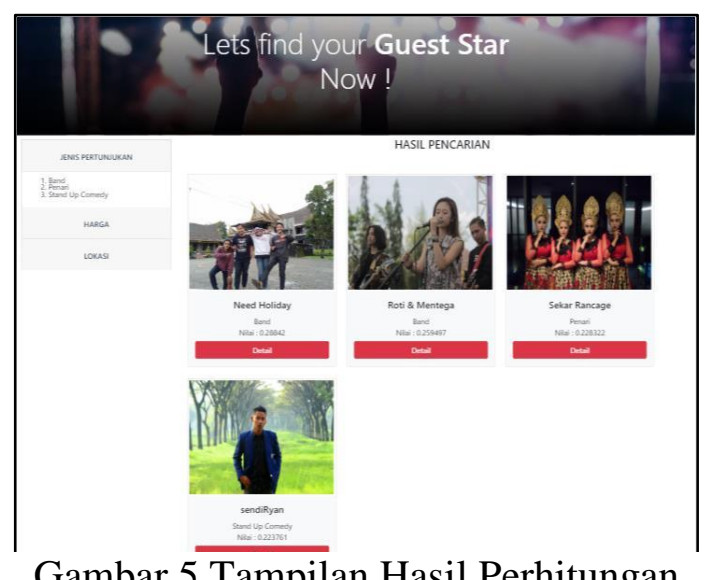

Pada Gambar 6 merupakan implementasi untuk detail guest star, dimana penyelenggara dapat melihat detail informasi dari masing-masing guest star. Kemudian di bawah detail informasi ada formulir penawaran kepada guest star. Jika tertarik untuk mengajukan tawaran, user dapat mengisi formulir dan mengirimnya. Kemudian di sisi guest star akan menerima email pemberitahuan dan penawaran akan masuk pada dashboard guest star.

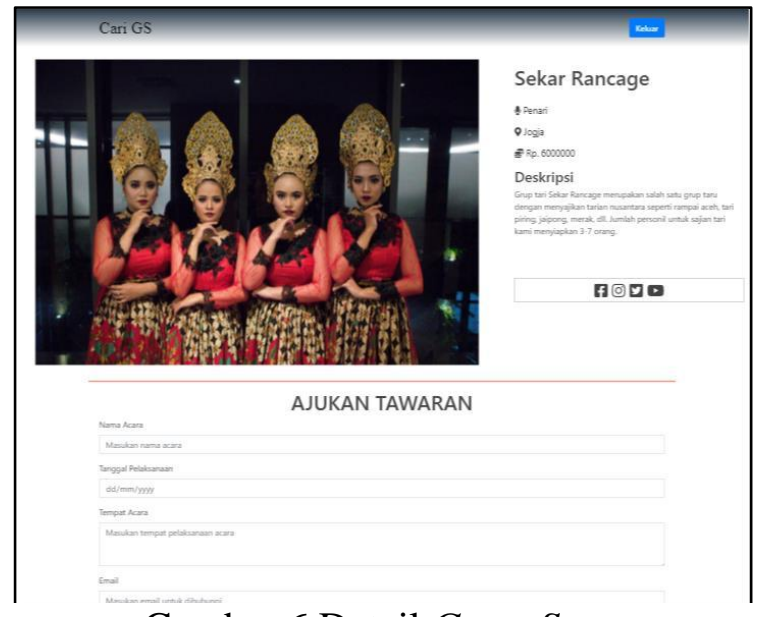

Gambar 6 Detail Guest Star

\subsubsection{Implementasi dashboard}

Pada Dashboard, pengisi event/guest star selaku user dapat memperbarui profil yang akan tampil di halaman e-marketplace, memperbarui akun untuk login ke dashboard. Dan yang terpenting, pengisi event/guest star dapat melakukan konfirmasi tawaran yang masuk apakah diterima atau ditolak. Pada Gambar 7 merupakan implementasi untuk halaman menu utama, dimana akan ditampilkan informasi guest star secara singkat. Selain itu juga terdapat menu tawaran untuk guest star dapat melihat dan mengonfirmasi tawaran yang masuk. Kemudian ada menu profil yang dapat digunakan untuk melihat dan memperbarui informasi guest star. Dan yang terakhir menu akun yang digunakan untuk memperbarui password. 


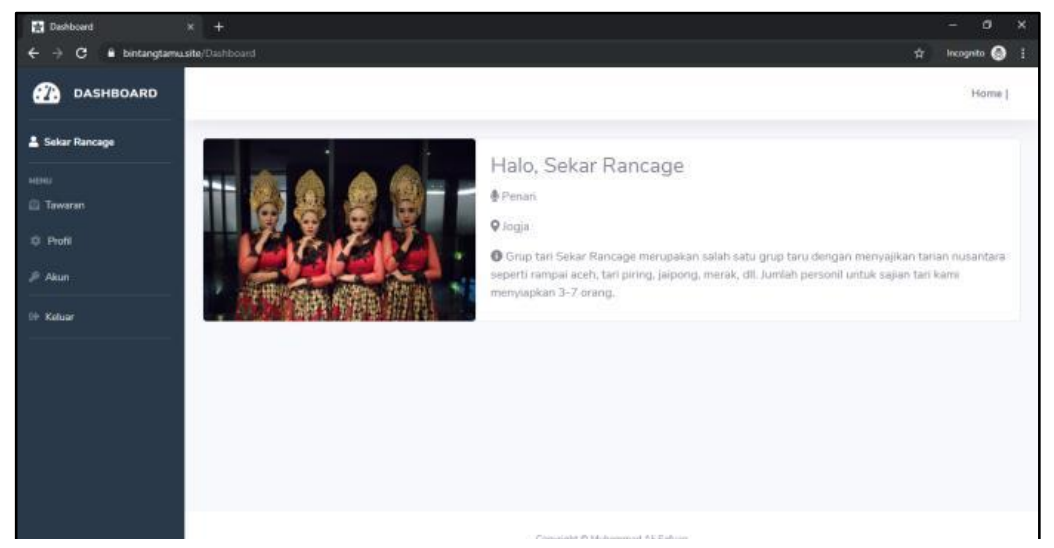

Gambar 7 Menu Utama Dashboard

Pada Gambar 8 merupakan implementasi untuk detail tawaran, dimana akan ditampilkan informasi lengkap dari tawaran yang sudah masuk seperti nama penyelenggara yang mengajukan, alamat event, tanggal event dan deskripsi event. Nantinya guest star dapat melakukan konfirmasi apakah permintaan itu di terima atau ditolak. Setelah melakukan konfirmasi, nantinya di sisi penyelenggara event yang mengajukan tawaran tersebut akan menerima email konfirmasi.

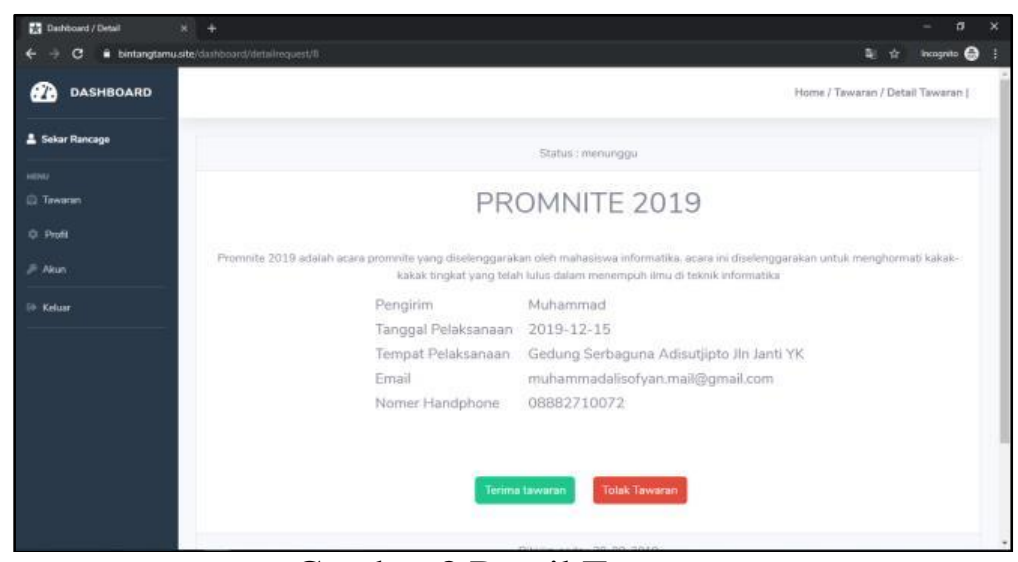

Gambar 8 Detail Tawaran

\subsection{Pembahasan}

Pada contoh kasus, penyelenggara event harus memasukan terlebih dulu urutan prioritas yang ada di menu utama.

a) Untuk kriteria jenis pertunjukan, urutan prioritas yang dimasukan adalah :

1) Prioritas pertama adalah Band

2) Prioritas kedua adalah Penari

3) Prioritas ketiga adalah Stand Up Comedy

b) Sedangkan, untuk kriteria lokasi urutan prioritas yang dimasukan adalah :

1) Prioritas pertama adalah Jogja

2) Prioritas kedua adalah Sleman

3) Prioritas ketiga adalah Bantul

4) Prioritas keempat adalah Gunung Kidul

5) Prioritas kelima adalah Kulon Progo

Adapun data yang ada sebagai berikut:

1. Terdapat tiga kriteria yang digunakan dalam menentukan guest star pada $e$-marketplace. yaitu: 
$\mathrm{K} 01=$ Jenis pertunjukan, merupakan jenis hiburan apa yang ditampilkan oleh guest star (contoh: band, penari, standup comedy).

K02 = Harga, merupakan nomimal uang yang harus dibayarkan kepada guest star untuk bisa tampil di sebuah event (contoh: 1000000).

K03 = Lokasi, merupakan tempat dimana guest star itu berada (contoh: Sleman, Bantul, Jogja).

2. Alternatif didapat dari guest star yang telah mendaftar pada sistem. Ada sejumlah alternatif yang ada dan terdaftar dalam $e$-markteplace yaitu :
A01 = Roti \& Mentega
A02 = Sekar Rancage
A03 = sendiRyan
A04 = Need Holiday
A05 = Sanggar Titik Dua
A06 = Babysha and The Oldface
A07 = Ingsun Jati
A08 = Aly Akbar
A09 = Frengki Sermadi

Langkah 1. Rating Kecocokan Alternatif dan Kriteria

Pada langkah awal ini menentukan rating kecocokan dari setiap alternatif dengan kriteria yang ada, rating kriteria K01 dan K03 didapatkan pada saat user memasukan urutan prioritas di halaman utama, rating tersebut memiliki nilai berurutan dari prioritas pertama sampai dengan prioritas akhir. Untuk K01 karena ada tiga prioritas yang harus diurutkan, maka :

1. Prioritas pertama akan bernilai 3

2. Prioritas kedua akan bernilai 2

3. Prioritas ketiga akan bernilai 1

Untuk K03 karena ada lima prioritas yang harus diurutkan maka :

1. Prioritas pertama akan bernilai 5

2. Prioritas kedua akan bernilai 4

3. Prioritas ketiga akan bernilai 3

4. Prioritas keempat akan bernilai 2

5. Prioritas kelima akan bernilai 1

Sedangkan untuk K02 kriteria harga, tidak menggunakan prioritas seperti kriteria yang lain, melainkan langsung diambil dari harga asli guest star tersebut supaya perbandingan selisih nominalnya lebih jelas. 
Tabel 1 Rating Kecocokan Alternatif dan Kriteria

\begin{tabular}{|l|l|c|c|c|}
\hline \multirow{2}{*}{ No. } & \multirow{2}{*}{ Alternatif } & \multicolumn{3}{|c|}{ Kriteria } \\
\cline { 3 - 5 } & & K01 & K02 & K03 \\
\hline 1. & A01 & 3 & 2800000 & 1 \\
\hline 2. & A02 & 2 & 6000000 & 5 \\
\hline 3. & A03 & 1 & 1500000 & 4 \\
\hline 4. & A04 & 3 & 4000000 & 3 \\
\hline 5. & A05 & 2 & 7000000 & 2 \\
\hline 6. & A06 & 3 & 5000000 & 3 \\
\hline 7 & A07 & 2 & 3000000 & 4 \\
\hline 8 & A08 & 1 & 2000000 & 3 \\
\hline 9 & A09 & 3 & 5000000 & 5 \\
\hline
\end{tabular}

Pada Tabel 4.1, untuk K01 adalah nilai dari kriteria jenis pertunjukan, untuk K02 adalah nilai dari harga guest star, dan untuk K03 adalah nilai dari lokasi guest star.

\section{Langkah 2. Bobot Kriteria}

Pada langkah kedua, tentukan bobot setiap kriteria. Bobot kriteria diambil dari data yang sudah didapatkan dari presentase hasil kuisioner yang telah dilakukan, sehingga :

1. Jenis pertunjukan mendapatkan presentase $52.8 \%$, kemudian didapatkan bobot 0.52 dari presentase tersebut.

2. Harga mendapatkan presentase $27.8 \%$, kemudian didapatkan bobot 0.27 dari presentase tersebut.

3. Lokasi mendapatkan presentase $19.4 \%$, kemudian didapatkan bobot 0.19 dari presentase tersebut.

Untuk atribut yang digunakan adalah benefit dan cost. Pada atribut benefit, jika nilai semakin tinggi maka akan semakin menguntungkan, seperti pada kriteria K01 dan K03 jika semakin tinggi nilai bobotnya maka akan semakin menguntungkan bagi penyelenggara event. Sedangkan pada atribut cost, semakin rendah nilainya maka akan semakin menguntungkan, seperti kriteria K02 jika semakin rendah harga guest star maka akan semakin menguntungkan bagi penyelenggara event. Atribut benefit akan bernilai positif dalam perhitungan vektor $\mathrm{S}$, sedangkan atribut cost akan bernilai negatif.

Tabel 2 Bobot Kriteria

\begin{tabular}{|l|l|c|c|c|}
\hline No & Kriteria & Deskripsi & Bobot & Atribut \\
\hline 1. & K01 & Jenis pertunjukan & 0.52 & benefit \\
\hline 2. & K02 & Harga & 0.27 & cost \\
\hline 3. & K03 & Lokasi & 0.19 & benefit
\end{tabular}

\section{Langkah 3. Normalisasi Bobot W}

Pada langkah ini, bobot awal yang sudah didapatkan $\mathrm{W}=(0.52,0.27,0.19)$, akan dilakukan perbaikan, sehingga $\Sigma W_{i}=1$. Adapun perhitungannya berdasarkan persamaan 2, dimana $W_{i}$ adalah hasil bobot awal dibagi total bobot semua kriteria adalah sebagai berikut:

$$
\begin{aligned}
& W_{1}=\frac{0,52}{0,52+0,27+0,19}=0,530612 \\
& W_{2}=\frac{0,27}{0,52+0,27+0,19}=0,275510
\end{aligned}
$$


Asih Pujiastuti, Anggraini Kusumaningrum, Muhammad Ali Sofyan

$$
W_{3}=\frac{0,19}{0,52+0,27+0,19}=0,193878
$$

\section{Langkah 4. Menentukan Nilai Vektor S}

Langkah ke empat adalah menentukan nilai vektor $\mathrm{S}$ dengan menggunakan persamaan 2, dimana $S$ adalah preferensi alternatif dianalogikan sebagai vektor $S$, dan i adalah alternatif (dimana $\mathrm{i}=1,2,3, \ldots \mathrm{n}$ ). adalah hasil dari nilai setiap kriteria $(x)$ dipangkatkan bobot setiap kriteria $(w)$. Sedangkan adalah pangkat bernilai positif untuk atribut benefit, dan bernilai negatif untuk atribut cost. sehingga didapatkan perhitungan sebagai berikut:

$S_{1}=\left(3^{0.530612}\right)\left(2800000^{-0,275510}\right)\left(1^{0,193878}\right)=0,029985$
$S_{2}=\left(3^{0.530612}\right)\left(6000000^{-0,275510}\right)\left(1^{0,193878}\right)=0,026779$
$S_{3}=\left(3^{0.530612}\right)\left(1500000^{-0,275510}\right)\left(1^{0,193878}\right)=0,026011$
$S_{4}=\left(3^{0.530612}\right)\left(4000000^{-0,275510}\right)\left(1^{0,193878}\right)=0,033631$
$S_{5}=\left(3^{0.530612}\right)\left(7000000^{-0,275510}\right)\left(1^{0,193878}\right)=0,021488$
$S_{6}=\left(3^{0.530612}\right)\left(5000000^{-0,275510}\right)\left(1^{0,193878}\right)=0,031625$
$S_{7}=\left(3^{0.530612}\right)\left(3000000^{-0,275510}\right)\left(1^{0,193878}\right)=0,031042$
$S_{8}=\left(3^{0.530612}\right)\left(2000000^{-0,275510}\right)\left(1^{0,193878}\right)=0,022725$
$S_{9}=\left(3^{0.530612}\right)\left(5000000^{-0,275510}\right)\left(1^{0,193878}\right)=0,034918$

\section{Langkah 5. Menghitung Nilai Vektor V}

Pada langkah terakhir, setelah masing-masing vektor didapat nilainya, langkah selanjutnya adalah menjumlahkan vektor $\mathrm{S}$ untuk menghitung vektor $\mathrm{V}$ yang digunakan perankingan, dengan menggunakan persamaan 3 yang telah disederhanakan, sehingga menjadi seperti berikut :

$$
\begin{aligned}
& \mathrm{V}_{1}=\frac{0,029985}{0,029985+0,026779+0,026011+0,033631+0,021488+0,031625+0,031042+0,022725+0,034918}=0,116131 \\
& \mathrm{~V}_{2}=\frac{0,026779}{0,029985+0,026779+0,026011+0,033631+0,021488+0,031625+0,031042+0,022725+0,034918}=0,103713 \\
& V_{3}=\frac{0,026011}{0,029985+0,026779+0,026011+0,033631+0,021488+0,031625+0,031042+0,022725+0,034918}=0,100737 \\
& V_{4}=\frac{0,033631}{0,029985+0,026779+0,026011+0,033631+0,021488+0,031625+0,031042+0,022725+0,034918}=0,130249 \\
& V_{5}=\frac{0,021488}{0,029985+0,026779+0,026011+0,033631+0,021488+0,031625+0,031042+0,022725+0,034918}=0,083222 \\
& V_{6}=\frac{0,031625}{0,029985+0,026779+0,026011+0,033631+0,021488+0,031625+0,031042+0,022725+0,034918}=0,122482 \\
& V_{7}=\frac{0,031042}{0,029985+0,026779+0,026011+0,033631+0,021488+0,031625+0,031042+0,022725+0,034918}=0,120221 \\
& V_{8}=\frac{0,022725}{0,029985+0,026779+0,026011+0,033631+0,021488+0,031625+0,031042+0,022725+0,034918}=0,088012 \\
& V_{9}=\frac{0,034918}{0,029985+0,026779+0,026011+0,033631+0,021488+0,031625+0,031042+0,022725+0,034918}=0,135234
\end{aligned}
$$

Dari perhitungan yang dihasilkan menurut inputan prioritas dari user melalui $e$ - marketplace penentuan guest star, didapatkan nilai dari yang terbesar hingga yang paling kecil, sehingga dapat diurutkan hasil tersebut untuk pe-ranking-an seperti pada Tabel 3. 
Tabel 3 Perankingan Alternatif

\begin{tabular}{|c|c|c|c|}
\hline Aternative & Nilai V & Rangking & Prosentase(\%) \\
\hline A01 & 0,116131 & 5 & 11,6 \\
\hline A02 & 0,103713 & 6 & 10,4 \\
\hline A03 & 0,100737 & 7 & 10,1 \\
\hline A04 & 0,130249 & 2 & 13,0 \\
\hline A05 & 0,083222 & 9 & 8,3 \\
\hline A06 & 0,122482 & 3 & 12,3 \\
\hline A07 & 0,120221 & 4 & 12,0 \\
\hline A08 & 0,088012 & 8 & 8,8 \\
\hline A09 & 0,135234 & 1 & 13,5 \\
\hline
\end{tabular}

\section{Kesimpulan}

Berdasarkan hasil implementasi dan pengujian yang telah dilakukan, maka dapat disimpulkan bahwa:

1. Program e-marketplace ini dapat digunakan untuk menentukan guest star dari alternatif-alternatif yang telah terdaftar pada sistem, penyelenggara event dapat terbantu dalam menentukan guest star mana yang akan dipilih berdasarkan hasil rangking tertinggi dari perhitungan weighted product.

2. Pengujian hasil implementasi sudah sesuai dengan perhitungan weighted product, yaitu guest star yang mempunyai hasil rangking tertinggi dari keseluruhan adalah Frengki Sermadi $(13,5 \%)$, sedangkan guest star yang mempunyai hasil rangking terendah dari keseluruhan adalah Sanggar Titik Dua $(8,8 \%)$.

\section{Daftar Pustaka}

[1] Nugroho, A. S.2016. E-Commerce Teori Dan Implementasi.Ekuilibria.Yogyakarta.

[2] Kardianawati, A., Haryanto, H., \& Rosyidah, U. 2016. Implementasi Konsep Appreciative Inquiry Dalam Model Gamifikasi Pada E-Marketplace. In Seminar Riset Teknologi Informasi (SRITI) (pp. 122-127)

[3] Turban, E., Aronson, J. E., \& Liang, T. P. (2005). Sistem Pendukung Keputusan dan Sistem Cerdas. Yogyakarta: Andi.

[4] Kusrini, M. K., \& Kom, M. 2007. Konsep dan Aplikasi Sistem Pendukung Keputusan. Andi Offset. Yogyakarta

[5] Pujiastuti, A., \& Ardiansyah, F. (2019). Decision Support System for The Weaning of Rex Rabbit Using Simple Additive Weighting (SAW) Method. Compiler, 8(1), 71-80.

[6] Honggowibowo, A. S., Pujiastuti, A., \& Suryanto, S. (2017). Sistem Pendukung Keputusan Pemilihan Destinasi Wisata Favorit di Propinsi YOGYAKARTA dengan Metode Weighted Product (Wp) Berbasis Android. Compiler, 6(2).

[7] Yoon, K. P., \& Hwang, C. L. 1995. Multiple Attribute Decision Making: An Introduction (Vol. 104). Sage publications.

[8] Nofriansyah, D., Kom, S., \& Kom, M. 2015. Konsep Data Mining Vs Sistem Pendukung Keputusan. Deepublish.

[9] Kusumadewi, S., Hartati, S., Harjoko, A., \& Wardoyo, R. 2006. Fuzzy Multi-Attribute Decision Making (Fuzzy MADM). Graha Ilmu. Yogyakarta 
Asih Pujiastuti, Anggraini Kusumaningrum, Muhammad Ali Sofyan

[10] Hartono, J. 2005. Analisis dan Desain Sistem Informasi: Pendekatan Terstruktur Teori Dan Praktek Aplikasi Bisnis. Andi. Yogyakarta 